\title{
IMMUNOGENICITY OF LOW-DOSE INTRAMUSCULAR AND INTRADERMAL VACCINATION WITH RECOMBINANT HEPATITIS B VACCINE
}

Marília Dalva TURChI(1), Celina Maria Turchi MARTELli(1), Maria Lúcia FERRAZ(2), Antonio Eduardo SILVA(2), Divina das Dores de Paula CARDOSO(1), Pierpaolo MARTELLI(1) \& Lilian Joy W. Antunes OLIVEIRA(1)

\begin{abstract}
SUMMARY
The study is a randomized trial using recombinant DNA vaccine to determine whether an intramuscular $10 \mu \mathrm{g}$ dose or intradermal $2 \mu \mathrm{g}$ induces satisfactory anti-HBs levels compared to the standard dose of intramuscular $20 \mu \mathrm{g}$. Participants were 359 healthy medical and nurse students randomly allocated to one of the three groups: Group I - IM $20 \mu \mathrm{\mu g}$; Group II - IM $10 \mu \mathrm{g}$; Group III - ID $2 \mu \mathrm{g}$ at 0,1 and 6 months. Anti-HBs titres were measured after complete vaccine schedule by ELISA/Pasteur. Baseline variables were similar among groups and side effects were mild after any dose. Vaccinees in the IM-10 $\mathrm{g}$ group had seroconversion rate and geometric mean titre (GMT $2344 \mathrm{IU} \mathrm{L}^{-1}$ ), not significant different from the IM-20 $\mu \mathrm{g}$ group (GMT $4570 \mathrm{IU} \mathrm{L}^{-1}$ ). On the contrary, $21.4 \%$ of the ID $-2 \mu \mathrm{g}$ recipients mount antibody concentration below $10 \mathrm{IU} \mathrm{L}^{-1}$ and GMT of $91 \mathrm{IU} \mathrm{L}^{-1}$, a statistically significant difference compared with the standard schedule IM-20 $\mu \mathrm{g}(\mathrm{p}<0.001)$. A three dose regimen of half dose IM could be considered an appropriate schedule to prevent hepatitis B in young health adults which is of relevance to the expansion of hepatitis B vaccine programme.
\end{abstract}

KEYWORDS: Hepatitis B vaccination; Immunization; Low doses.

\section{INTRODUCTION}

Vaccines against hepatitis $\mathrm{B}$ have been available for more than a decade ${ }^{10.25 .26}$ however, the incidence of the infection is still high reflecting the difficulties in vaccination ${ }^{1.23}$. Since the restricted policy of targeting high-risk groups, known as selective strategy, has failed to give significant reduction of the disease, universai vaccination of ail infants and children has been recommended ${ }^{27.11 .15 .21}$. Nevertheless, the cost of the full schedule has hampered the implementation of a universal vaccination policy, particularly in developing countries.

Currently Brazilian policy recommends selective vaccination in low prevalence areas and universal immunization during childhood in areas of high endemicity - Amazon Basin, Santa Catarina and Espirito Santo States. An expansion of vaccination to all infants in routine basis is being planned by the Ministry of Health after $1997^{\circ}$. The universal strategy encouraged by the World Health Organization" would provide a long term solution, however, there is a cohort of susceptible adolescents/young adults requiring immediate preventive measure.
In general, young healthy adults are not a target group for vaccination unless they are from special high risk groups defined by occupation or lifestyle. Different strategies considering costeffectiveness have been proposed to expand the vaccination to young adults since there are difficulties to identify high risk groups ${ }^{1.2 .11 .15}$. Several studies addressed the question whether a dose reduction by intradermal route would give the similar protection as the full recommended dose as alternative schedules to reduce cost. Most of these studies tested the plasma derived hepatitis $\mathrm{B}$ vaccine and the efficacy of low dose DNA recombinant vaccine being still a matter of controversy 4.6 .9 .12 .210 .27 .30 .

The objective of the present study is to determine whether a $10 \mu \mathrm{g} I \mathrm{M}$ or $2 \mu \mathrm{g}$ ID of recombinant DNA hepatitis $\mathrm{B}$ vaccine induce satisfactory anti-HBs levels compared to the standard dose of $20 \mu \mathrm{g}$ IM. The results may be useful to draw recommendations of vaccination programs for adolescents and health care workers as an affordable public health policy.

(1) Universidade Federal de Goiás, Goiânia. Goiás, Brasil.

(2) Universidade Federal de São Paulo, São Paulo, SP, Brasil

Correspondence to: Dra Marília Dalva Turchi. Instituto de Patologia Tropical e Saúde Pública. Rua Delenda Rezende de Melo s/n, Setor Universitírio. $74605-(050$ Goiânial. GO, Brazil. Fax: (062) 261-6414. 
TURCHI, M.D.; MARTELLI. C.M.T.; FERRAZ, M.L.; SILVA. A.E.; CARDOSO, D.D.P.; MARTELLI, P. \& OLIVEIRA, L.J.W.A. - Immunogenicity of low-dose intramuscular and intradermal vaccination with recombinant hepatitis B vaccine. Rev. Inst. Med. trop. S. Paulo, 39(1): 15-19. 1997.

\section{MATERIAL AND METHODS}

Study design - The study is a randomized three arm preventive trial, conducted between 1993 and 1994. The vaccine used was the recombinant DNA yeast-derived hepatitis B (Engerix-B, manufactured by SmithKline Beecham Biologicals, Rixensart, Belgium), stored and handled according to the manufacturer recommendation.

Study population - The participants were recruited from among healthy medical or nurse students at Federal University of Goiás - Central Brazil. To be eligible for the trial, the participants had to test negative for the antibody to HBV core antigen (anti-HBc) at the beginning of the study and they did not recall previous hepatitis $B$ vaccination. Of 385 students HBV screened at the trial entry $6.7 \%$ were anti-HBc positives and they were excluded from the study:

The eligible students $(\mathrm{N}=359)$ were randomly allocated to a three dose 0,1 and $6-$ month schedule, $20 \mu \mathrm{g}$ IM (IM-20) or $10 \mu \mathrm{g}$ IM (IM-10) administered into the deltoid muscle or $2 \mu \mathrm{g}$ ID (ID-2) into the volar aspect of the forearm. The participants who completed the three dose schedule had a serum sample collected to determine anti-HBs levels after 1 to 3 months of the full vaccine course". Side effects were actively investigated before each subsequent dose or recorded by passive report. Weight and height were recorded by self-report. The body mass index (BMI) was calculated as weight in kilograms divided by the square of the height in meters $^{24}$. Smoking was defined as smoking cigarettes at baseline.

The study protocol was approved by the local Ethics Committee and vaccine and serological tests were offered at no cost. Participants gave written informed consent before enrollment. The anti-HBc positive individuals were also tested by anti-HBs and HBsAg markers, for immunity and carrier status assessment for medical follow-up and counselling. Although individuals with anti-HBc as a sole marker of infection were excluded from the trial, they were offered a full course of $\mathrm{HB}$ vaccine ${ }^{14}$. The participants who deviated from the protocol were also offered the full dose schedule but excluded from the analysis.

Laboratory techniques - All blood samples were centrifugated and serum was stored at $-20^{\circ} \mathrm{C}$ until assayed. HBV screening (anti-HBc) was performed by Enzyme Immunoassay (ELISA) using commercial reagents (Corzyme, Abbott Laboratories, USA) at Instituto de Patologia Tropical e Saúde Pública/ Federal University of Goiás. Seropositive ones were also tested for anti-HBs and HBsAg by Elisa (Abbott Laboratories, USA).

Post-vaccine samples were tested for hepatitis B virus surface antibody (anti-HBs) by a third generation two-step sandwich enzyme immunoassay (Monolisa anti-HBs, Sanofi Diagnostics Pasteur, France). Serological assays were undertaken on sera from 304 participants sent blindly to the Federal University of São Paulo, São Paulo. Samples found to be positive were titrated using a standard curve of known anti-HBs concentration (Sanofi Diagnostics Pasteur, France). The criteria for protection was defined as concentration of anti-HBs $\geq 10 \mathrm{IU} \mathrm{L}^{-1}$.
Statistical analysis - The data were analyzed using SPSS/ PC (SPSS Inc., Chicago, IL, USA, 1987). The chi-square test or Fisher test were used for comparison of proportions as appropriate. The anti-HBs titres were transformed in the $\log _{10}$ scale, and the geometric mean titre (GMT) with $95 \%$ confidence interval were calculated. Comparison between means of any two groups were performed by Student's t-test of log-transformed titres ${ }^{13}$. The sample size of 90 individuals was chosen to ensure that there would be at least $90 \%$ power to detect a difference of $95 \%$ vs $80 \%$ with a level of 0.025 (one-sided).

\section{RESULTS}

Three hundred and fifty nine students were randomized. 135 subjects received IM-20, 112 were on the group of IM-10 and 112 received ID-2 schedule. The age ranged from 17 to 28 years and females accounted for $56.3 \%$ of the total sample. Compliance to the protocol was achieved by 304 individuals whose seroconversion rates were available. Table 1 shows the baseline characteristics of the subjects. Sex, mean age, BMI and smoking habits were similar among the groups.

TABLE 1

Baseline characteristics of the study population.

\begin{tabular}{lccc}
\hline Variables & $\begin{array}{c}\text { IM 20 } \boldsymbol{\mu g} \\
(\mathbf{N}=\mathbf{1 1 4})\end{array}$ & $\begin{array}{c}\text { IM 10 } \boldsymbol{\mu g} \\
(\mathbf{N}=\mathbf{9 2})\end{array}$ & $\begin{array}{c}\text { ID 2 } \boldsymbol{\mu g} \\
(\mathbf{N}=\mathbf{9 8})\end{array}$ \\
\hline Age (years) & $20.0(1.9)$ & $20.3(2.3)$ & $20.1(1.8)$ \\
Mean (SD) & $17-28$ & $17-26$ & $17-2.5$ \\
Range & 59.6 & 57.6 & 52.0 \\
Females (\%) & $21.1(2.2)$ & $21.6(3.9)$ & $21.4(2.5)$ \\
Body Mass Index (SD) & 1.8 & 1.1 & 1.0 \\
Current Smokers (\%) & & & \\
\hline
\end{tabular}

Table 2 shows the frequency of seroconversion rates $\left(\geq 10 \mathrm{IU} \mathrm{L}^{-1}\right)$ and the geometric mean of anti-HBs titre (GMT) for each group. Only one student in the full dose schedule and 5 students in the half dose were not protected at the end of the trial follow-up. Therefore, one hundred and thirteen students out of 114 had protective antibody response for the $20 \mu \mathrm{g}$ schedule which corresponds to $99.1 \%(95 \%$ CI 95.1-100.0). For the 10$) \mu$ IM group 87 out of 92 also mount antibody protective levels yiclding $94.6 \%$ (95\% CI 87.6-98.6). The overlap of confidence intervals denotes no statistically significant difference in the proportions between these two groups. On the contrary, the seroconversion was statistically lower for the ID group than for $20 \mu \mathrm{g} I \mathrm{M}$ vaccine recipients $\left(\mathrm{X}^{2}=21.7 \mathrm{p}<0.001\right)$. The geometric mean titre of anti-HBs in persons immunized with IM-10 was not statistically different compared to the $20 \mu \mathrm{g}$ IM group. For the ID group the GMT was $91 \mathrm{IU} \mathrm{L}^{-1}$, less than one-fifty of the $20 \mu \mathrm{g}$ IM (GMT 4570 IU L L $\mathrm{L}^{-1}$, t-test $\mathrm{p}<0.001$.

The distribution of anti-HBs titres for the groups are shown in Table 3. Intramuscular administration resulted in GMTs cat- 
TURCHI, M.D.; MARTELLI, C.M.T.; FERRAZ. M.L.; SILVA. A.E.; CARDOSO, D.D.P.; MARTELLI, P. \& OLIVEIRA. L.J.W.A. - Immunogenicity of low-dose intramusculat and intradermal vaccination with recombinant hepatitis B vaccine. Rev. Inst. Med. trop. S. Paulo, 39(1): 15-19, 1997.

TABLE 2

Seroconversion rate and geometric mean titres (GMT) of anti-HBs against hepatitis B vaccine according to dose and via of administration.

\begin{tabular}{lcccc}
\hline Group & N & Seroconversion & $(95 \%$ CI) & GMT (SD) \\
\hline IM 20 $\mathrm{gg}^{*}$ & 114 & $99.1 \%$ & $(95.1-100)$ & $4.570(7.8)$ \\
IM 10 $\mathrm{gg}^{*}$ & 92 & $94.6 \%$ & $(87.6-98.6)$ & $2344(16.2)$ \\
ID 2 $\mu \mathrm{g}^{*}$ & 98 & $78.6 \%$ & $(68.6-86.6)$ & $91(15.5)$ \\
\hline
\end{tabular}

GMT t-test

GMT t-test ${ }^{(* \text { versil } क)} \mathrm{p}<0.001$

egories of similar magnitudes. There was no significant difference in the distribution of concentration among the IM recommended dose and the IM half dose schedule. In the IM-10 group, $71.8 \%$ of vaccinees had very high levels of antibody in excess of $1000 \mathrm{IU} \mathrm{L}^{-1}$. On the contraty, $19.4 \%$ of the ID-2 recipients mount antibodies at concentrations above $1000 \mathrm{IU} \mathrm{L}^{-1}$.

TABLE 3

Frequency distribution of anti-HBs concentration within a given range according to vaccine groups.

\begin{tabular}{|c|c|c|c|}
\hline Titre $\left(\mathbf{I U ~ \mathbf { L } ^ { - 1 } )}\right.$ & $\begin{array}{c}\text { IM } 20 \mu \mathrm{g} \\
\text { n }(\%)\end{array}$ & $\begin{array}{c}\text { IM } 10 \mu \mathrm{g} \\
\text { n }(\%)\end{array}$ & $\begin{array}{c}\text { ID } 2 \mu \mathrm{g} \\
\mathrm{n}(\%)\end{array}$ \\
\hline$<10$ & $1(0.9)$ & $5(5.4)$ & $21(21.4)$ \\
\hline $10-99$ & $5(4.4)$ & $7(7.6)$ & $16(16.3)$ \\
\hline $100-999$ & $16(14.0)$ & $14(15.2)$ & $42(42.9)$ \\
\hline $1000-9999$ & $44(38.6)$ & $31(33.7)$ & $17(17.3)$ \\
\hline$\geq 10000$ & $48(42.1)$ & $35(38.1)$ & $2(2.1)$ \\
\hline
\end{tabular}

Side effects were mild in the three groups after any dose. For the purpose of analysis the side effects of the IM group vaccinees were pooled. Low grade fever were reported by $2.4 \%$ of ID vaccinees and by $1.1 \%$ of the IM group. For the local adverse reactions recorded as itching erythema, swelling/induration or hyperpigmented macule, $62.3 \%$ occurred in the ID and $2.7 \%$ in the IM group $\left(X^{2}=122.3, p<0.001\right)$. Therefore local reactions were commoner in the ID than in the IM group. The report of local pain was low and not statistically different for IM and ID administered route, respectively $3.5 \%$ and $8.4 \%\left(X^{2}=1.5, p=0.2\right)$.

The proportion of non-compliers to the protocol was similar for the three groups (19.3\% for the standard $20 \mu \mathrm{g}$ IM; $17.9 \%$ for $10 \mu \mathrm{g}$ IM and $12.5 \%$ for $2 \mu \mathrm{g}$ ID). They were also similar according to age and sex. Therefore it is unlikely that the loss of these subjects introduced any bias in the study results.

\section{DISCUSSION}

The immunologic response to low doses of Hepatitis B vaccine either by IM or ID route in healthy young adults was measured by two parameters: the rate of seroconversion and the con- centration of anti-HBs in comparison to the standard dose. There were no significant differences in the variables sex, age, body mass index and smoking status among the randomized groups. These variables are known to influence the antibody response after vaccination ${ }^{16.28 .31}$

In this study, the immunogenicity of DNA-derived $\mathrm{HB}$ vaccine was evaluated by the proportion of seroconversion and by the anti-HBs titres. Results were similar for the $20 \mu \mathrm{g}$ and $10 \mu \mathrm{g}$ IM groups. However, both parameters were significantly lower for the $2 \mu \mathrm{g}$ ID group and vaccine nonresponders represented around $25 \%$ of the ID recipients. Furthermore, considering that the administration of ID injections in this trial was performed by well trained personnel under optimal conditions, it seems reasonable to believe that this strategy should encounter some technical difficulties under routine conditions resulting in even lower rates of seroconversion. Another disadvantage of ID route is the requirement of checking post-vaccination protective antibody levels and providing booster doses more frequently than otherwise. This approach implicates obvious increases in costs and decreases in compliance making the ID route unsuitable for large scale programs.

These findings of low response rate among ID vaccines using DNA - recombinant vaccine were also found in a few reports ${ }^{9,18.31}$. Recently, a study conducted among heahth workers showed that and alternative schedule of ID- $2 \mu \mathrm{g} 2$ doses even with a third booster dose of IM-20 $\mu \mathrm{g}$ was not effective to provide immunity ${ }^{17}$. On the contrary, a high response rate after ID vaccination has been demonstrated by several studies using plasma-derived vaccine ${ }^{12.20127}$. In Brazil, an assessment of ID route for plasma derived vaccine yielded $88.9 \%$ (80/90) seroconversion rates among one group of health workers ${ }^{6}$ compared to our result $(78.6 \%)$. One possible explanation for the differences obtained from these two studies is that the administration of low intradermal doses of DNA-recombinant vaccine has been considered to mount lower antibody response than the plasma-derived ones ${ }^{4.18}$

There is an official recommendation of half-dose of standard DNA-vaccine for children under 11 years old in many countries $^{7.8}$. Our findings showing that $10 \mu \mathrm{g}$ is as effective as $20 \mu \mathrm{g}$ could justify the use of half dose in older age-groups, including adolescents and young adults, with implications of considerable cost reduction in mass vaccination program. Similar results of immunogenicity were also achieved in a trial among high school 
TURCHI. M.D.; MARTELLI, C.M.T.; FERRAZ, M.L.; SILVA, A.E.; CARDOSO. D.D.P.; MARTELLI, P. \& OLIVEIRA, L.J.W.A. - Immunogenicity of low-dose intramusculiı and intradermal vaccination with recombinant hepatitis B vaccine. Rev. Inst. Med. trop. S. Paulo, 39(1): 15-19, 1997.

adolescents in Thailand ${ }^{10}$ and among US military force younger than 30 years 5 .

It is still a matter of controversy whether the absolute values of GMT achieved as early response to hepatitis B vaccination predicts duration of protection ${ }^{4.21 .29}$. Since the present study was not designed to evaluate the duration of the protective anti-HBs levels, the long-term efficacy of hepatitis $B$ vaccination with reduced dose could be answered by further assessment of antibody status or by detecting breakthrough infection in prolonged follow-up of large cohorts of vaccinees.

Although the participants were medical and nurse students previously informed about hepatitis B hazards and vaccine safety, the non-adherence to the correct dose interval schedule was the main cause of lost to follow-up and for excluding individuals from analysis. Adverse reactions seemed to have played a minor role among the reasons for not uptaking the vaccine since severe side-effects were absent from the groups and from the students who completed the three-dose schedule at different time-intervals. Our study corroborates the results of poor awareness of hepatitis $B$ vaccination schedule among health workers which might influence the effectiveness of vaccination programs in health care settings ${ }^{3}$. Evaluation of antibody protection at different intervals of vaccine administration would probably best simulate the real situation in a mass program, however, this approach was beyond the scope of the present intervention.

In conclusion this study supports the use of $10 \mu \mathrm{g}$ DNA-recombinant vaccine for older age-groups beyond the 11 -years-old recommendation. We believe that the extension of this low dose strategy for at least one more decade for adolescents and young healthy adults in combination with the already planned universal infant vaccination should be considered as an affordable public health policy for developing countries.

\section{RESUMO}

\section{Avaliação da resposta imunogênica da vacina recombinante de hepatite $B$ em baixas doses por via intramuscular e intradérmica}

São relatados os resultados de um ensaio randomizado utilizando vacina de DNA recombinante com o objetivo de determinar se doses de $10 \mu \mathrm{g}$ intramuscular (IM) ou $2 \mu \mathrm{g}$ intradérmica (ID) induzem resposta protetora em comparação com a dose padrão $20 \mu \mathrm{g}$ IM. 359 estudantes de Medicina e Enfermagem que não apresentaram marcador viral da hepatite $B$ foram aleatoriamente alocados para um dos três grupos: Grupo I - $20 \mu \mathrm{g}$ IM; Grupo II - $10 \mu \mathrm{g}$ IM; Grupo III - $2 \mu \mathrm{g}$ ID com esquema vacinal de 0,1 e 6 meses. Os títulos de anti-HBs foram medidos após completar o esquema vacinal empregando técnica de ELISA (Pasteur). As características de base entre os grupos foram semelhantes e os efeitos colaterais foram leves após qualquer das doses. Os vacinados com $10 \mu \mathrm{g}$ IM apresentaram taxa de soroconversão e média geométrica de títulos (GMT $\left.2344 \mathrm{IU} \mathrm{L} \mathrm{L}^{-1}\right)$ não significantemente diferentes do grupo que recebeu $20 \mu \mathrm{g}$ IM (GMT $4570 \mathrm{IU} \mathrm{L}^{-1}$ ). Ao contrário, 21,4\% dos vacinados com $2 \mu \mathrm{g}$ ID não apresentaram resposta protetora e a GMT foi de $91 \mathrm{IU} \mathrm{L}^{-1}$, uma diferença estatisticamente significante comparada com o esquema padrão $20 \mu \mathrm{g}$ IM $(\mathrm{p}<0,001)$. O esquema vacinal utilizando 3 doses de $10 \mu \mathrm{g}$ IM induziu resposta protetora adequada em adultos jovens, tendo este resultado possíveis implicações para a expansão do programa de controle da hepatite $\mathrm{B}$.

\section{ACKNOWLEDGEMENTS}

This work was partly supported by grant from FUNAPE and Hospital das Clínicas da Universidade Federal de Goiás - Brasil. Vaccines were provided by Ministry of Health and Secretariat of State. We thank Dr. João Alves de Araújo Filho for his help in field work. We would also like to thank Dr. Crésio Romeu Pereira for suggestions in the early draft of this manuscript.

Conflict of interest none.

\section{REFERENCES}

1. ALTER, M.J.; HADLER, S.C.; MARGOLIS. H.S. et al. - The changing epidemiology of hepatitis $B$ in the United States. Need for alternative vaccination strategies. J. Amer. med. Ass., 263:1218-1222. 1990.

2. BLOOM, B.S.; HILLMAN, A.L.; FENDRICK, A.M. \& SCHWARTZ. J.S. - A reappraisal of hepatitis $B$ virus vaccination strategies using cost-effectiveness analysis. Ann. intern. Med., 118:298-306, 1993

3. BRIGGS, M.J. \& THOMAS, J. - Obstacles to hepatitis B vaccine uptake by health care staff. Publ. HIth., 108:137-148, 1994.

4. BRYAN. J.P.; SJOGREN, M.H.; PERINE, P.L. \& LEGTERS. L.J. - Low-dose intradermal and intramuscular vaccination against hepatitis B. Clin. infect. Dis., 14:697-707, 1992

5. BRYAN, J.P.; CRAIG, P.G.; REYES, L. et al. - Randomized comparison of 5 and 10 microgram doses of two recombinant hepatitis B vaccines. Vaccine, 13:978-982, 1995

6. CARRILHO. F.J.; QUEIROZ. M.L.: SILVA, L.C. et al. - Active immunization against hepatitis $B$ virus (HBV) with low-doses of plasma-derived valccine by intradermal route. Rev. Inst. Med. trop. S. Paulo, 31:91-94, 1989.

7. CASTILlO, E.; BENSABATH, G. \& MORAES, D. - Hepatites vimis, In: GUIA DE VIGILÂNCIA EPIDEMIOLÓGICA. Brasília, Ministério da Saúde, 1994 p. 179-196.

8. CENTERS FOR DISEASE CONTROL - Protection against viral hepatitis Recommendations of the Immunization Practices Advisory Commitee (ACIP) MMWR, 39(S-2):10-14, 1990

9. CENTERS FOR DISEASE CONTROL - Inadequate immune response among public safety workers receiving intradermal vaccination against hepatitis B. United Stites, 1990-91. MMWR, 40:569-572, 1991.

10. DIEnstaG, J.L. - Toward the control of hepatitis B. New Engl. J. Med., 303:874-876, 1980

11. GLOBAL ADVISORY GROUP - Expanded programme of immunization. Wkly. Epidem. Rec., 3:1]-15, 1992.

12. KING. J.W.: TAYLOR, E.M.; CROW, S.D. et al. - Comparison of the immunogenicity of hepatitis $B$ vaccine administered intradermally and intramuscularly. Rev. infect. Dis., 12:1035-1043, 1990.

13. KIRKWOOD, B.R. - Essentials of medical statistics. Oxford, Blackwell Scientific Publications, 1988. p. 138-146 
TURCHI, M.D.; MARTELLI, C.M.T.; FERRAZ, M.L.; SILVA, A.E.; CARDOSO, D.D.P.; MARTELLI, P. \& OLIVEIRA, L.J.W.A. - Immunogenicity of low-dose intramusculal and intradermal valecination with recombinant hepatitis B valccine. Rev. Inst. Med. trop. S. Paulo, 39(1): 15-19, 1997.

14. LOK, A.S.F.: LAI, C.L. \& WU, P.C. - Prevalence of isolated antibody to hepatitis $B$ core antigen in an area endemic for hepatitis B virus infection: implications in hepatitis B vaccination programs. Hepatology, 8:766-770, 1988

15. MANGTANI, P.; HALL, A. I. \& NORMAND, C.E.M.- Hepatitis B valccination: the cost effectiveness of alternatives strategies in England and Wales. J. Epidem. comm. Hlth., 49:238-244, 1995.

16. MORRIS, C.A.; OLIVER, P.R.; REYNOLDS, F. \& SELKON, J.B. - Intradermal hepatitis $B$ immunization with yeast-derived vaccine: serological response by sex and age. Epidem. Infect., 103:387-394, 1989.

17. OliveirA. P.M.C.; SILVA, A.E; KEMP, V.L. et al. - Comparison of three different schedules of vaccination against hepatitis $B$ in health care workers. Vaccine, 13:791-794. 1995.

18. PAYTON. C.D.: SCARISBRICK. D.A.: SIKOTRA, S \& FLOWER, A.JE Vaccination against hepatitis $B$ : comparison of intradermal and intramuscular administration of platsma derived and recombinant vaccines. Epidem. Infect., 110:177-180, 1993.

19. POOVORAWAN. Y.; PONGPUNLERT, W.; THEAMBOONLERS, A. et al. Randomized. single-blind comparison of the immunogenicity and reactogenicity of 20 micrograms and 10 micrograms doses of hepatitis B vaccine in adolescents. Southeast Asian J. trop. Med. publ. HIth., 24:255-259, 1993.

20. REDFIELD, R.R.; INNIS, B.L.; SCOTT, R.M. et al. - Clinical evaluation of low-dose intradermally administered hepatitis B virus vaccine. J. Amer. med. Ass., 254:3203-3206, 1985.

21. SCHAFFNER, W. GARDNER, P. \& GROSS, P.A. - Hepatitis B immunization strategies: expanding the target. Ann. intern. Med., 118:308-309, 1993.

22. SCHIFMAN, R.B.; RIVERS. S.L.; SAMPLINER, R.E. \& KRAMMES. J.E. Significance of isolated hepatitis B core antibody in blood donors. Arch. intern. Med., 153:2261-2266. 1993.
23. SHAPIRO, C.N. \& MARGOLIS, H.S. - Hepatitis B epidemiology and prevention. Epidem. Rev. 12:221-227. 1990

24. SHETTY, P.S.; IAMES. W.P.T. \& FERRO-LUZZI. A. - Malnutrition and the immune response. 1. Malnutrition in the community: recent concepts. Trans. roy. Soc. trop. Med. Hyg., 88:612-614, 1994

25. SZMUNESS, W.; STEVENS. C.E.; HARLEY, E.J. et al. - Hepatitis B vilccine demonstration of efficacy in a controlled clinical trial in a high-risk population in the United States. New Engl. J. Med., 303:833-841. 1980

26. SZMUNESS, W.; STEVENS, C.E.; HARLEY, E.J. et al. - Hepatitis B valecine in medical staff of hemodialysis units. New Engl. J. Med., 307:1481-1486. 1982.

27. WAHL, M. \& HERMODSSON, S. - Intradermal, subcutaneous or intramusculal administration of hepatitis B vaccine: side effects and antibody response. Scand. J. infect. Dis., 19:617-621, 1987.

28. WEBER, D.J.; RUTALA, W.A.; SAMSA, G.P. et al. - Obesity als a predictor of poor antibody response to hepatitis B plasma vaccine. J. Amer. med. Ass., $254: 3187-3189,1985$

29. WHITTLE, H.C.; MAINE, N.; PILKINGTON, J. et al. - Long-term efficalcy of continuing hepatitis $B$ vaccination in infancy in two Gambian villages. Lancet, 345:1089-1092. 1995.

30. WISTROM, J.; SETTERGREN, B.; GUSTAFSSON, A. et al. - Intradermal vs intramuscular hepatitis B vaccinations. J. Amer. med. Ass., 264:18 I-182.1990.

31. WOOD, R.C.; MACDONALD, K.L.; WHITE. K.E. et al. - Risk factors for lack of detectable antibody following hepatitis $B$ vaccination of Minnesota health carre workers. J. Amer. med. Ass., 270:2935-2939. 1993.

Recebido para publicação em 13/09/1996

Aceito para publicação em 03/02/1997 
